\title{
IRANIAN HIGH SCHOOL EFL LEARNERS' ATTITUDE TOWARDS ONLINE LEARNING DURING THE COVID-19 PANDEMIC
}

\section{Fatemeh Jalilinia}

Department of Persian Literature and Foreign Languages, Allameh Tabatabai University, Iran

Corresponding Author Email: en.fjalilinia@yahoo.com

\begin{tabular}{ll}
\hline \hline Article Info & Abstract \\
\hline Article History & By the outbreak of the Covid-19 pandemic, students and teachers were pushed to \\
Received: September 2021 & adapt themselves to the online learning system. The current study is a \\
Revised: October 2021 & quantitative attempt to investigate English as a foreign language students \\
Published: October 2021 & perception of online learning during the pandemic. For this purpose, 30 male \\
Keywords & and 30 female students at the high school level were chosen to answer a \\
Covid-19; & questionnaire in Iran, Tehran. The questionnaire used in this study is adopted \\
Interaction; & from Rojabi (2020) and comprises two parts. The first half assesses the \\
Learning environment; & interaction among students and between students and the teacher whereas the \\
Online learning; & second half measures students attitude towards their online learning platform. \\
& The data was interpreted through the SPSS software (version 24) and the results \\
& revealed that learners mainly have negative perspectives on online learning and \\
& would not suggest it for further educational years to come. The majority of \\
participants struggled with having effective interaction. Also, most of them did & not have pleasant experiences with the learning platform they were instructed to \\
& use. It is recommended that the current learning environment be improved and \\
& teachers apply strategies to involve students fully in the learning process \\
throughout online sessions.
\end{tabular}

How to cite: Jalilinia, F. (2021). Iranian High School EFL Learners' Attitude towards Online Learning during the Covid-19 Pandemic, JOLLT Journal of Languages and Language Teaching, 9(4), pp. 442-451. DOI: https://doi.org/10.33394/jollt.v\%vi\%i.4225

\section{INTRODUCTION}

Prior to the Covid-19 pandemic, some universities in Iran had adopted the online approach for education, but none of the schools had applied this way of teaching. With the arrival of the pandemic, all the schools and universities were forced to use online education as a way of maintaining everyone's health. Zayapragassarazan (2020) states that if students learn materials actively, then online learning would be useful. This means students need to be given a chance to be creative and overcome difficulties. In the EFL classroom, the teacher helps students enhance their listening, speaking, reading, and writing skills by getting them involved and keeping them motivated through different stages of learning. Based on what students need, there are several methods for teachers to employ, one of which is online learning (Rojabi, 2020).

Even before the pandemic, many studies had been done on online learning because the internet is taking over every aspect of human life, and education is not an exception to that. Today, online learning is even of greater importance because knowing how to apply it is necessary for keeping everyone healthy. Therefore, it's vital to determine a platform for it. The ministry of education in Iran has developed an application called "Shad" to be used by elementary, junior high school, and senior high school students and teachers (Ministry of Education of Iran, 2020). It is necessary to know the perception of learners towards this platform in order to determine its flaws and merits and improve it for future uses. The purpose of this study is to figure out whether high school EFL students have a positive or negative attitude towards online learning via the Shad platform and whether or not they're satisfied 
with the level of interaction in such classes. Accordingly, the current study aims to answer these questions: How has online learning during Covid-19 affected interaction among EFL learners and with their teacher? And what are EFL learner's attitudes towards online learning via Shad application during the Covid-19 pandemic? Also, the following sentences are the hypotheses formed for this research. First: Online learning does not affect EFL students' interaction. Second: Students have a neutral attitude towards online learning via the Shad platform.

\section{Review of literature}

\section{Online learning prior to Covid-19}

Even before the Covid-19 outbreak, investigation on online education interested many researchers. A study has been done on the attitude of EFL students towards e-Learning and online class' effect on the success of learners by Erarslan and Zehir Topkaya (2017). In this quantitative study, the COMPLEQ (Comparative Learning Environment Questionnaire) has been used to find out university students' attitudes towards e-learning and face-to-face learning. Some findings of this study were that students give little time to completing activities and do not put a value on online classes because they don't believe online education to be useful, so they prefer face-to-face classes. The researchers also mentioned that online classes didn't help with the success of students. According to Wright (2017), because students have better understanding and interaction with their classmates and teachers in face-to-face classes, they believe such classes to be more motivating. However, other students who favored online classes believed them to be convenient and flexible in terms of not having any time or place constraints.

Moreover, students' perceptions of different platforms have been explored. For example, Manowong (2016) has researched to find out EFL students' thoughts on the Edmodo learning tool. It was reported that students had positive attitudes towards Edmodo. This platform was mentioned to be convenient, and students could also actively take part in classes. On the other hand, some negative points of this tool were discussed, and it was mentioned that this platform could waste the time of students who weren't completely familiar with technology. Also, following the procedures was reported to be hard. Another study by Srichanyachon (2014) shows that students who had a positive attitude on using the internet for learning had more positive viewpoints towards using Learning Management System (LMS) than the rest.

\section{Online learning during Covid-19}

Many studies have been done on online learning amidst the Covid-19 outbreak. Tanjung and Utomo (2021), have investigated EFL undergraduate students' perception of online learning in Indonesia through a questionnaire that included demographic information and students' thoughts on the learning environment before and after the Covid-19 pandemic. The results showed students had different amounts of familiarity with social media and educational websites and that the use of these platforms has increased slightly, which is due to the government's instructions to use these platforms for learning. Also, cheating, copying, and network problems have been reported as disadvantages of online learning. On the whole, both positive and negative perceptions of online learning were noted. Furthermore, a study in Saudi Arabia explored 379 female EFL students' engagement in online courses through Student Course Engagement Questionnaire (SCEQ). The findings revealed teachers should be engaged in the learning process and change their position of authority to that of a supportive member. Other results showed that students were very much engaged in the online class (Oraif \& Elyas, 2021).

Also, Anwar and Wahid (2021) have done research to find out students' perceptions of online learning. The questionnaire they used in this study included both close-ended and 
open-ended questions that focused on learners' participation, teacher's role, and instructional design and delivery. The writers concluded from the results that students were content with instructional design and delivery of online classes. However, they believed there was still room for improvement. Students also complained about internet connection problems. Another finding was that students weren't satisfied with the level of interaction during online classes. The authors suggested that teachers be more encouraging and have the role of facilitator.

In Pakistan, Adnan and Anwar (2020), have done a study on 126 higher education students to perceive their perspectives on online education. They used an adapted version of Bernard, Brauer, Abrami, and Surkes's (2004) questionnaire for this purpose. It was concluded from the data analysis that students believed traditional classes were more efficient than online classes. The writers stated that in under-developed countries such as Pakistan, online learning could not have effective outcomes. Another study was done by Lengkanawati, Wirza, and Alicia (2020), in which EFL students' views on online learning were examined through online interviews with six learners. The results showed that learners agreed with online learning as the best way of education during the Covid-19 pandemic, although face-toface learning was believed to be more effective. Another point was that instructors do not have enough experience with online teaching.

Cabangacala, Alieto, Estigoy, Delos Santos, and Torres (2021) have investigated college learners' technological competence and attitude towards online learning. For this purpose, they used the Attitude towards Online Learning Questionnaire and Technological Competence Tool (Javier, 2020). The results showed that participants' attitudes were somehow positive, and they were somehow competent in the technological area. Also, perception of online learning and technological competence were reportedly related.

\section{Online learning in the Iranian context}

Other studies have investigated online learning in the Iranian context. Erfani and Ghapanchi (2019) have investigated English and engineering students' understanding of elearning via both qualitative and quantitative instruments. In the quantitative phase, students showed positive attitudes, and in the qualitative phase, they mentioned online classes should be recorded. They also had some suggestions on making interaction in online classes effective, and they believed online learning to be useful for people with full-time or part-time jobs. Based on what students mentioned, time and money efficiency, being able to work and have education simultaneously, and recording classes were some advantages of this type of learning. Some disadvantages named by students were: professors not being familiar with online education and their negative attitude towards it, lack of suitable interaction, and limitations regarding technology. Mahmoodi Shahrebabaki (2014) has mentioned the challenges of e-learning in Iran in his study, some of which are the absence of government and public awareness, e-learning being expensive, difficulties with the internet speed and filtering, and sanctions. He advised that the government be supportive of online learning and its costs, enhance the speed of the internet and introduce some alternative websites for the ones that cannot be accessed because of sanctions. Also, they suggest that public awareness of e-learning be raised, and students rely on themselves instead of the traditional classroom.

According to Yaghoubi, Malek Mohammadi, Iravani, Attaran, and Gheidi (2008), students' attitudes towards virtual learning depend on students' assessment of e-learning competency, internet access, internet and computer utilization, and detecting the flaws of the education system. In another study, Heirati and Alashti (2015) explored Iranian EFL students' and teachers' thoughts of online learning. They also wanted to check whether there were any differences between male and female participants' attitudes towards online learning. To 
achieve this goal, they used the questionnaire of Teachers' Attitude toward Internet for Language Learning and Learners' Attitude toward Internet for Language Learning. The results proved the respondents' attitudes to be positive. Also, no difference between the males' and females' attitudes towards the use of internet for learning was reported. There are more researches conducted on online learning in higher education, but few studies have been done on high school students. The current study intends to discover high school students' perception of online learning regarding their English class during the Covid-19 pandemic.

\section{RESEARCH METHOD \\ Research Design}

Towards the end of the educational year, in order to find out students' perception of online learning during the educational year which was held completely virtual, a qualitative method was adopted and a questionnaire which is constructed of two parts was given to students. It's notable that the reliability of this questionnaire was tested via Cronbach's alpha method, and the value was 0.956 , which is greater than 0.7 , so the data is considered reliable. The validity was tested through the Pearson correlation method, and the r-value for all questions was greater than the r-table so the questions are considered valid (Rojabi, 2020). The population of this study includes high school EFL learners in district 12 of Tehran. 30 male and 30 female EFL students at the high school level in district 12 in Tehran were chosen from two schools through random sampling, and they were asked to fill out the questionnaire.

\section{Instruments}

The questionnaire used in this study has two parts. The first part focuses on students' interaction among themselves and with their teacher, and the second part assesses the learning environment. This questionnaire was adopted from Rojabi (2020). According to Rojabi (2020), the first portion of the questionnaire which is concentrated on interaction, was made by Gray (2016), and the second part which is focused on the learning environment, was developed by Fortune (2011). This questionnaire has 16 items, on the whole, with each part having eight items, and it is based on a five-point Likert scale which is: Strongly Agree (5), Agree (4), Neutral (3), Disagree (2), and Strongly Disagree (1).

\section{Data Analysis}

The questionnaire was translated to the Persian language by the author to avoid confusion for students. The questionnaire was given to students via the Google Forms website, and after collecting learners' responses, the data were analysed via the SPSS software (version 24). The results of the analysis are presented in the following sections.

\section{RESEARCH FINDINGS AND DISCUSSION Research Findings}

The results of the questionnaire regarding students' perception of interaction during online learning are the following:

Table 1

The number of participants who took the questionnaire on student interaction

\begin{tabular}{lcccccccc}
\hline Criteria & Item 1 & Item 2 & Item 3 & Item 4 & Item 5 & Item 6 & Item 7 & Item 8 \\
\hline Strongly agree & 2 & 5 & 5 & 12 & 5 & 5 & 5 & 4 \\
\hline Agree & 13 & 11 & 20 & 25 & 8 & 13 & 26 & 16 \\
\hline Neutral & 10 & 13 & 10 & 8 & 16 & 15 & 12 & 14 \\
\hline Disagree & 24 & 20 & 12 & 11 & 20 & 14 & 12 & 16 \\
\hline Strongly disagree & 11 & 11 & 13 & 4 & 11 & 13 & 5 & 10 \\
\hline Total & 60 & 60 & 60 & 60 & 60 & 60 & 60 & 60 \\
\hline
\end{tabular}


Based on students' responses to the questionnaire, results are given in the percentage form below:

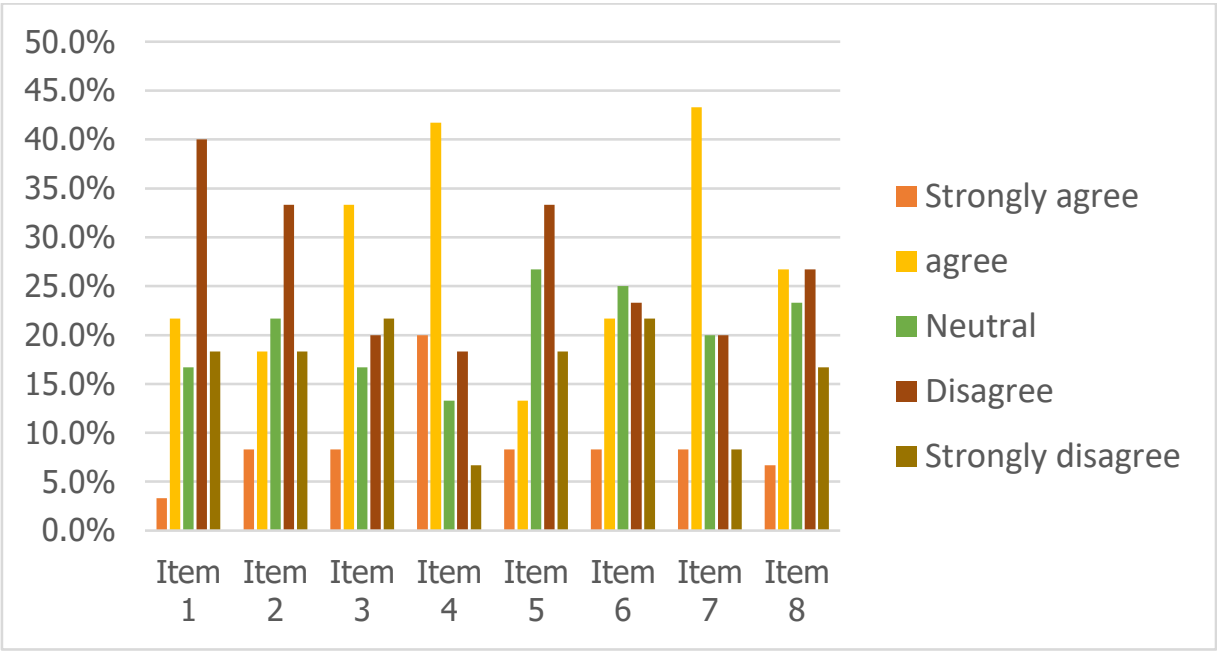

Figure 1. Students' perception of interaction in the online class as percentage

Table2

Leaners' attitudes in the first half of the questionnaire regarding the interaction

\begin{tabular}{ccccccc}
\hline & N & Maximum & Minimum & Mean & Std. Deviation & Std. Error Mean \\
\hline Learners & 60 & 5.00 & 1.25 & 2.6750 & 0.68124 & 0.08795 \\
\hline
\end{tabular}

The given mean for students in the interaction part of the questionnaire is 2.6750 , which demonstrates learners mostly have negative standpoints regarding the level of interaction among themselves and with their teachers in their online classes. The following are students' perceptions of their learning environment in the online class, which is the Shad application:

Table 3

The number of participants who took the questionnaire on the learning environment

\begin{tabular}{lcccccccc}
\hline Criteria & Item & Item & Item & Item & Item & Item & Item & Item \\
& $\mathbf{9}$ & $\mathbf{1 0}$ & $\mathbf{1 1}$ & $\mathbf{1 2}$ & $\mathbf{1 3}$ & $\mathbf{1 4}$ & $\mathbf{1 5}$ & $\mathbf{1 6}$ \\
\hline Strongly agree & 2 & 2 & 3 & 8 & 4 & 2 & 2 & 1 \\
\hline Agree & 2 & 2 & 3 & 23 & 0 & 1 & 9 & 2 \\
\hline Neutral & 7 & 9 & 4 & 12 & 10 & 8 & 13 & 6 \\
\hline Disagree & 26 & 22 & 18 & 11 & 13 & 20 & 18 & 11 \\
\hline Strongly disagree & 23 & 25 & 32 & 6 & 33 & 29 & 18 & 40 \\
\hline Total & 60 & 60 & 60 & 60 & 60 & 60 & 60 & 60 \\
\hline
\end{tabular}

The results of the questionnaire regarding the learning environment are given below according to percentage: 


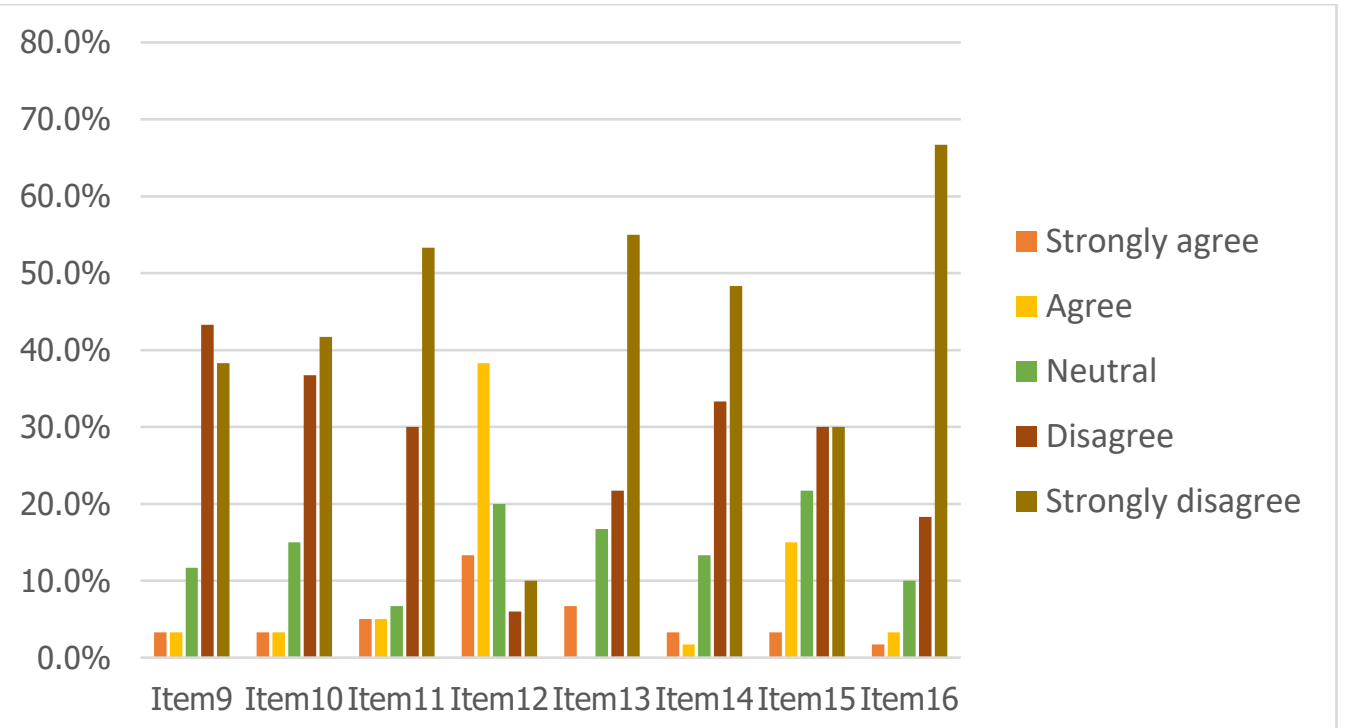

Figure 2. Students' perception of the learning environment in online class as percentage

Table 4

Learners' attitude in the second half of the questionnaire regarding the learning environment

\begin{tabular}{lcccccc}
\hline & N & Maximum & Minimum & Mean & $\begin{array}{c}\text { Std. } \\
\text { Deviation }\end{array}$ & $\begin{array}{c}\text { Std. Error } \\
\text { Mean }\end{array}$ \\
\hline Learners & 60 & 5.00 & 1.00 & 2.0396 & 0.80171 & 0.10350 \\
\hline
\end{tabular}

According to table 4, learners' mean in the second part of the questionnaire is 2.0396, which shows students' perception of the Shad learning environment is mainly negative.

\section{Discussion}

This study aims to find out English as a foreign language students' perception of online learning during the pandemic. Online learning has been applied in EFL teachers around the world because it helps students to communicate with their teachers during Covid-19 pandemic virtually. To know the students' perception, this study distributes some items to be answered by them. Item1: Online learning makes me easier to interact with the lecturer. Almost $58 \%$ of students disagree with this statement, while $25 \%$ of them agree with it and $17 \%$ were neutral about it. This shows that students usually have trouble interacting with their teacher in the online class. Without social presence, interaction is hard, and in this case, it seems that students are not satisfied with online interaction with their teacher.

Item2: Interaction with lecturers becomes closer in online learning. Approximately $51 \%$ of students disagree, $27 \%$ agree and $22 \%$ are neutral about it. It can be said that most of the students are not comfortable and cannot communicate with their teachers well. The internet connection and technological devices available to students may affect this item. Then, Item3: Expressing the problems faced in online learning to the lecturers is more comfortable than face to face. $41.7 \%$ of students disagree with this assertion, $41.6 \%$ agree with it and $17 \%$ are neutral. The results of this item were interesting since the number of students who were in favor of this sentence and who were opposed to it is nearly equal. The reason behind it may be the fact that this item particularly depends on each student and each personality. So based on students' characteristics, the responses differ.

Item4: Miscommunication between lecturers and students often happens in online classes. $24 \%$ of students expressed their disagreement, almost $62 \%$ of them showed agreement and the other $14 \%$ were neutral. The majority of students showed dissatisfaction 
when it came to their communication with their teachers. Considering the fact that these students were quite familiar with the internet and technology, this result can be due to teachers' being unskillful in using online learning tools.

Item5: Online lecture makes interactions between students easier. Around $22 \%$ of learners agreed with this statement, while $51 \%$ were opposed to it and almost $27 \%$ of them had neutral stances. The results show that most EFL learners cannot interact appropriately with each other. Since students cannot have face-to-face interactions with each other, it's difficult for them to form friendships. Therefore, it's harder for them to connect with each other in online classes.

Item6: Interaction between students becomes closer in an online class. $30 \%$ of students were in favor of this statement, while $45 \%$ objected and $25 \%$ were neutral about it. It can be said that the greater number of learners had difficulty getting close to their classmates during the online class. Since students couldn't see or physically meet each other, it is hard for them to get to know one another. Item7: Miscommunication between students often occurs in online classes, for example in conducting the paper of presentation in the group. Approximately $52 \%$ of EFL learners agreed with this concept, while around $28 \%$ disagreed and $20 \%$ of the responses were neutral. This shows that learners cannot build appropriate communications with each other and may have difficulties handling a group project.

Item8: Overcoming complications between students becomes easier in online learning, for example, in completing the group paper. Almost $34 \%$ of students agreed with this concept, but $43 \%$ were skeptical about it and $23 \%$ had no opinion. This result indicates that most students cannot solve the problem at hand easily, and this can frustrate them. Item9: The learning environment in the online class helps me to understand the materials easier. Almost $7 \%$ of respondents agreed with this notion, while $81 \%$ challenged it and $12 \%$ were neutral about it. The results show that majority of students face difficulties understanding the material that is being taught. In order to compensate for this lack of learning, students could ask their questions in the WhatsApp group chat they shared with their teacher.

Item10: Learning environment in an online class arouses me to learn and understand the materials actively. Approximately $7 \%$ of learners agreed with this statement, but $78 \%$ responded negatively and $15 \%$ had neutral stances. Motivation is an important aspect to consider and since this research was done during the Covid-19 pandemic, the importance is even more highlighted. According to this data, EFL learners mostly find the Shad environment discouraging which is quite concerning because, with the impact of the pandemic on students' life and also their mental health, motivation could be the only factor that keeps them going and pushes them to study.

Item11: Learning environment in online learning pushes me to take online learning. $10 \%$ of students showed agreement, around $83 \%$ disagreed and $7 \%$ had no opinion on this matter. A high number of students do not enjoy online learning via the Shad application. This is because this application is slow and has not been appropriately designed. Therefore, students struggle with it. Item12: I feel comfortable answering questions in an online class. Almost $52 \%$ of respondents answered positively, while $16 \%$ opposed and $20 \%$ were neutral. Since in these online classes students couldn't see each other, they had fewer worries about saving face and consequently participated more.

Item13: I prefer to learn online than to learn face to face. Almost 7\% of learners were in favor of this concept, $77 \%$ rejected it and the other $17 \%$ had neutral stances. The unsuitable learning environment, various internet problems, and lack of proper communication all lead students to prefer face-to-face learning. Item14: Learning environment in the online learning gives me a huge contribution to study. Only $5 \%$ of students showed agreement, whereas almost $82 \%$ disagreed and $13 \%$ had a neutral attitude. Most learners do not find the Shad 
environment motivating which will cause them to grow tired of studying quickly and it will reduce the quality of learning.

Item15: Learning environment in online class makes it easier to find my learning needs. Around $18 \%$ of students agreed to this sentence, $60 \%$ objected and $21 \%$ answered neutrally. According to these results, the Shad platform isn't really helping students with recognizing their learning needs. From another viewpoint, students may not know their needs regardless of the learning environment, and that's why they chose the neutral option. Item16: I recommend conducting online learning in the future due to the comfortable learning environment. 5\% of respondents agreed, though $85 \%$ disagreed and $10 \%$ had a neutral view. A greater number of respondents do not suggest online learning in the future. This is because of the bitter experience these students have had with online learning. In face-to-face classes, they don't have any of the problems they deal with in online learning, so it's only natural that they have a negative point of view towards future online classes.

From the above results, it can be understood that the performance of online learning has not been fully desirable. According to figure1, online learning is not favorable to a high percentage of students and learners did not have easy or helpful interactions. So, to answer the first research question, it can be said that online learning has made the interactions become poor. Figure 2 shows that again, a high percentage of respondents, are not content with the Shad application as a learning platform. Therefore, as the answer to the second research question, it can be discussed that learners' attitudes towards learning English through this platform is mainly negative.

Abbasi, Hejazi and Hakimzade (2020), have reported some of the deficiencies of online learning via the Shad application which is in line with the findings of the current study. Those factors include the low level of motivation among students, the low speed and the high price of internet. Another study done by Haji, Mohammadi Mehr and Muhammad Azar (2021), describes some challenges of online learning through the Shad application some of which are students and parents related problems, teacher related problems and issues regarding facilities.

\section{CONCLUSION}

According to the findings, the Shad application has not provided a suitable learning environment for students during their online classes. The majority of participants in this study had negative attitudes towards the Shad platform. Moreover, respondents were mostly not satisfied with the level of interaction among themselves or with the teacher in online classes. Thus we can say that online learning has affected the interaction factor negatively in the EFL class. So both of the hypotheses are rejected. On the whole, the responses to the questionnaire show concerning results and indicate that serious changes should be applied in online learning at high schools. In order to have effective online learning, first, the current platform needs to be refined. Secondly, internet problems regarding the connection and the speed should be solved so that students can have a favorable online experience. Another aspect is, of course, training instructors to adapt themselves correctly to online teaching. They need to employ new techniques to catch students' attention and use their full potential in online classes. Assigning students to group projects in parallel online classrooms, flipped learning, getting learners involved by asking them to upload their projects, and using webcams are all ways of keeping the interaction level high in virtual classes.

This study gives an idea of EFL learners' attitudes towards online learning in Tehran, but since it was done on a rather small sample, the generalizability cannot be wide. Future research should focus on EFL learners' interaction and their learning environment through a broader sample in the Iranian context. 


\section{REFERENCES}

Abbasi, F., Hejazi, E., \& Hakimzade, R. (2020). Lived experience of elementary school teachers about the opportunities and challenges of teaching in the educational network of students (SHAD): A phenomenological study. Research in Teaching, 8(3), 24-1.

Adnan, M., \& Anwar, K. (2020). Online Learning amid the COVID-19 Pandemic: Students' Perspectives. Journal of Pedagogical Sociology and Psychology, 2(1), 45-51.

Anwar, I. W., \& Wahid, J. H. (2021). Learners' Perception on Online Learning Implementation During Covid-19 Pandemic. Journal of Languages and Language Teaching, 9(2), 126-138.

Bernard, R. M., Brauer, A., Abrami, P. C., \& Surkes, M. (2004). The development of a questionnaire for predicting online learning achievement. Distance education, 25(1), 31-47.

Cabangcala, R., Alieto, E., Estigoy, E., De Los Santos, M., \& Torres, J. M. (2021). When Language Learning Suddenly Becomes Online: Analyzing English as Second Language Learners'(ELLs) Attitude and Technological Competence. TESOL International Journal, 16(4.3), 115-131.

Erarslan, A, \& Zehir Topkaya, E. (2017). EFL students' attitudes towards e-learning and effect of an online course on students' success in English. The Literacy Trek, 3(2), 80101.

Erfani, M., \& Ghapanchi, Z. (2019). Attitudes toward E-learning in Ferdowsi University of Mashhad: Case of English and Engineering Students. Quarterly of Iranian Distance Education Journal, 2(1).

Fortune, M. F., Spielman, M., \& Pangelinan, D. T. (2011). Students' Perceptions of Online or Face-to-Face Learning and Social Media in Hospitality, Recreation and Tourism. MERLOT Journal of Online Learning and Teaching, 7(1), 1-16.

Gray, J. A., \& DiLoreto, M. (2016). The Effects of Student Engagement, Student Satisfaction, and Perceived Learning in Online Learning Environments. NCPEA International Journal of Educational Leadership Preparation, 11(1), 98-119.

Haji, J., Mohammadi Mehr, M., \& Muhammad Azar, H. (2021). Describing the Problems of virtual Education via Shad application in Corona Pandemic: This is a phenomenological study. Information and Communication Technology in Educational Sciences, 11(43), 153-174.

Heirati, J. K., \& Alashti, L. A. (2015). Attitudes toward using the Internet for language learning: A case of Iranian English teachers and learners. International Journal of Research Studies in Educational Technology, 4(1).

Lengkanawati, N. S., Wirza, Y., \& Alicia, D. (2021, January). EFL Learners' View on Online Learning Implementation During Covid-19 Outbreaks. In 4th Sriwijaya University Learning and Education International Conference (SULE-IC), 2020 (pp. 351-357). Atlantis Press.

Mahmoodi-Shahrebabaki, M. (2014). E-learning in Iran as a developing Country: Challenges Ahead and Possible Solutions. International Journal of Research in Education Methodology, 6(2), 788-795.

Manowong, S. (2016). Undergraduate students' perceptions of Edmodo as a supplementary learning tool in an EFL classroom. Humanities, Arts and Social Sciences Studies (Former Name Silpakorn University Journal of Social Sciences, Humanities, And Arts), 137-162.

Ministry of Education of Iran. (2020, April 9). شبكه /جتماعى دانش آموزان (شاد) آماده بهره بردارى شد) [Students' social network (shad) is ready to use] https://www.medu.ir/fa/news/item/1150867/ 
Oraif, I.; Elyas, T. (2021). The Impact of COVID-19 on Learning: Investigating EFL Learners' Engagement in Online Courses in Saudi Arabia. Education Sciences. 2021, 11, 99. 2-19.

Rojabi, A. R. (2020). Exploring EFL Students' Perception of Online Learning via Microsoft Teams: University Level in Indonesia. English Language Teaching Educational Journal, 3(2), 163-173.

Srichanyachon, N. (2014). EFL Learners' Perceptions of Using LMS. Turkish Online Journal of Educational Technology-TOJET, 13(4), 30-35.

Tanjung, F. Z., \& Utomo, A. (2021). Investigating EFL Students' Perception on Online Learning Amidst Covid-19 Pandemic. International Journal of Indonesian Education and Teaching (IJIET), 5(1), 102-115.

Wright, B. M. (2017). Blended learning: Student perception of face-to-face and online EFL lessons. Indonesian journal of applied linguistics, 7(1), 64-71.

Yaghoubi, J., Malek Mohammadi, I., Iravani, H., Attaran, M., \& Gheidi, A. (2008). Virtual Students' Perceptions of e-Learning in Iran. The Turkish Online Journal of Educational Technology, 7(3).

Zayapragassarazan, Z. (2020). COVID-19: Strategies for Online Engagement of Remote Learners. Jawaharlal Institute of Postgraduate Medical Education and Research (JIPMER), 9(246), 1-11. 